Newfoundland and Labrador Studies

\title{
Robert Finley, ed. Best Kind: New Writing Made in Newfoundland
}

\section{Nathan R. Elliott}

Volume 34, Number 2, 2019

URI: https://id.erudit.org/iderudit/1072658ar

DOI: https://doi.org/10.7202/1072658ar

See table of contents

Publisher(s)

Faculty of Arts, Memorial University

\section{ISSN}

1719-1726 (print)

1715-1430 (digital)

Explore this journal

Cite this review

Elliott, N. (2019). Review of [Robert Finley, ed. Best Kind: New Writing Made in Newfoundland]. Newfoundland and Labrador Studies, 34(2), 337-340.

https://doi.org/10.7202/1072658ar viewed online.

https://apropos.erudit.org/en/users/policy-on-use/ 
Robert Finley, ed. Best Kind: New Writing Made in Nerwfoundland. St. John's: Breakwater Books, 2018. ISBN 978-1-550-81716-4

Creative non-fiction, since the 1960s and the days of Truman Capote and Joan Didion, has been gaining momentum and is perhaps now eyeing ascendency. The auto-fiction novels of Norwegian writer Karl Ove Knausgaard dominated best-seller charts in one of the more surprising literary coups of the last decade. The magazine Creative Nonfiction enjoys a print circulation that far outweighs many other literary magazines devoted to fiction and poetry. This American Life, The Moth, and Confabulations bring true stories to live audiences and podcast listeners across Canada and the United States.

But why, exactly, does it matter if a story is true?

Would we regard The Iliad or Antigone as more interesting if the stories had been successfully fact-checked? Or — for that matter - is it even possible to tell a completely true story, given the uncertain swirls of memory, perspective, and epistemic bias? In the nineteenth century, we rushed to the photograph because of its promised verisimilitude; here, we thought, was a medium capable of representing the truth. In everything from the fairy hoaxes played on Sir Arthur Conan Doyle to the Zapruder film, to the advent of fake news, we've spent the past century and a half learning just how complicated a photograph's hold on the truth can be. Can we expect anything less epistemically complicated from a "true" story?

Or - to push these annoying questions even further - is it possible for any story worthy of being called a story to be utterly false? Reading the science fiction of Octavia Butler and reading her own non-fiction reflections on her writing career in her essays, I began to feel that her stories of interstellar gene traders expressed autobiographical truth about her experience as a six-foot tall African-American woman that transcended mere facts. And numerous commentators have noted that The Iliad seems to have an uncanny grip on the intimate horrors of war; the epic poem displays a gory emotional realism that sits comfortably alongside the metaphysical conceits of Greek 
gods that empiricism and logical positivism have branded with the epistemically shaky category of "false."

Still, we like true stories, and there's something about a story being "true" that a significant portion of readers want in their prose. Truman Capote might have made up any number of scenes in his ground-breaking non-fiction novel, In Cold Blood, but the pleasure of reading that book as fact is so distinct and horrifying that it propelled that book to classic status. Joan Didion's acid-dropping toddler in "Slouching Towards Bethlehem" is, in some way, more crucially compelling when we believe that the a young Didion did, in fact, meet such a toddler in the very real neighbourhood of Haight-Ashberry.

Best Kind, edited by Memorial University of Newfoundland's Robert Finley and published by Breakwater Books, enters these conversations and this peculiar moment in the genre with a cover that promises readers its pages comprise " $100 \%$ nonfiction." This is the kind of boast that almost demands closer scrutiny, and many of the 12 essays in this slender volume implicitly ask you to consider their own subjective judgment.

Michelle Porter and Bridget Canning, in two of the strongest entries in the book, make it clear that they are aware of how memory shapes story. Of course, their emphasis on their own subjectivity might well be a way of warding off charges of practising collateral fiction, but these moments can just as easily be read as part of the non-fiction writer's bag of storytelling amusements. We, in the audience, enjoy the truthful telling of a story that has been so flagged. When the writer is honest about her or his unconscious potential for humdrum fictional lies, the story becomes that much more real.

This is especially effective in Porter's case, as her sisterly tale of narrowly avoiding sexual molestation as children is repeatedly framed by time and memory. It's a true story, but it's also a gothic story, one in which Porter doesn't realize she was the hero until she's an adult, in the frame narrative, talking on the phone to the sister she saved. That frame provides a pleasing irony: the helpless female heroines of the British gothic were always repeatedly framed in narratives meant to 
lend verisimilitude to the story of barely thwarted rape by cruel aristocratic Catholic uncles; Porter's true story of the neighbourhood pervert provides a similar frame but conveys its reality via subjective judgment rather than locating it in the fixed text of the dusty, lost manuscript of so many gothic and horror tales.

Other narratives provided in Best Kind attack the form itself to underline subjectivity: Joan Sullivan's "Clive Wearing Writes (and Writes and Writes) His Autobiography" uses the subjectivity of the mind and a subversion of the genre of autobiography to get at the tenuous nature of identity, with an assist from the work of Oliver Sacks. Irene Velentzas's "Hidden in Plain Sight" also brings up the subjective nature of her own childhood memories, and plays those memories alongside the experience of watching her father's hold on memory fail as Alzheimer's takes its toll. The collection concludes with Paul Whittle's “A Sketch of Stephen," which follows the writer's teenage memory of a psychiatric patient who regains his memory for a brief week, some several years after he lost it.

There are more essay narratives in Best Kind, and it's possible that you might find essays in here that you like even more than the ones I have highlighted. The writing is strong and consistent throughout, and the book reads briskly. If there's a limitation here, it's that it doesn't highlight its own strength quite clearly enough. Many of the book's contributors bring subtle, interesting, possibly unconscious interrogations of the genre they are practising, and a clearer emphasis on the book's contribution to the genre as a whole might have made it an even more entertaining and provocative intervention in the genre than it is. Still, this is an entertaining book, and a consistently well-written book - especially impressive for an anthology that has little stated goal other than to gather creative non-fiction being written on the island of Newfoundland.

Are these stories utterly true, as the nostalgia-themed, touristfriendly cover proclaims?

Probably. Maybe not. Who cares?

These are some good stories, stories that make us think about how 
Book Reviews

stories - fiction and non-fiction alike - depend on the mind and the tongue of the teller.

Nathan R. Elliott

Montreal 